\title{
THE SILENCING OF STUDENT MOVEMENT AGAINST THE EGYPTIAN PRO-CAPITALISM GOVERNMENT IN RADWA ASHOUR'S NOVEL FARAJ
}

\author{
Shinta Fitria Utami ${ }^{1}$ \\ Betty Mauli Rosa Bustam ${ }^{2,3}$ \\ ${ }^{1}$ Jurusan Bahasa dan Sastra Arab, \\ Fakultas Adab dan Humaniora, \\ UIN Imam Bonjol Padang \\ ${ }^{2}$ Magister Pendidikan Agama Islam, \\ Fakultas Agama Islam \\ Universitas Ahmad Dahlan Yogyakarta \\ ${ }^{3}$ Email: betty.rosa@bsa.uad.ac.id
}

\begin{abstract}
This research is studying about novel Faraj. The novel contains an overview of the silencing the student movement's resistance during the capitalist government. This resistance rises due to the cooperation policy between Egypt and the U.S, which impact on intervention of the U.S in Egypt economic and political affairs. The Egyptian students begin, intensively, to discuss these issues, write numerous articles about resistance and criticism of the government, and perform various protests in Cairo. The method of data collecting data in this research consist of two phases, determines the research object and restriction on research problems that focused on an overview of events related to silencing the student movement. The method of data processing consists of determining the relevant theory to answer the problem, searching for references that support the research topic, analyzing the data in accordance with the related theory. The Result of this research indicates the silencing carried out against the anti-capitalist student movement in Egypt. The silencing was conducted through the destruction of the wall magazine, which publish numerous articles about resistance and criticism of the government, arrest, and torture. It happened because of the different interests between the government and the students.
\end{abstract}

Keywords: silencing; student movement; literary work; genetic structuralism; radwa ashour; faraj

$$
\begin{aligned}
& \text { ملخص } \\
& \text { تناول هذا البحث دراسة العمل الأدبي رواية فرج التى تحتوى على صور تخميد الأصوات التى تناديها حركة الطلبة فن }
\end{aligned}
$$

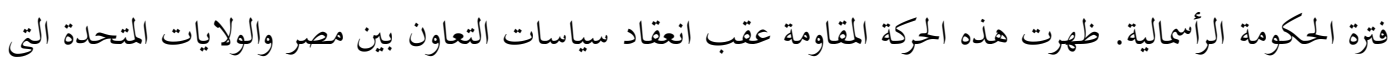

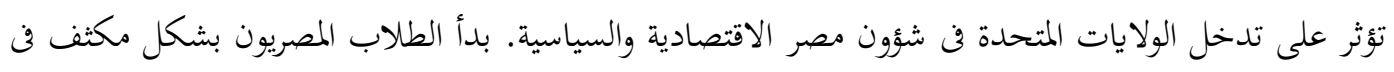

$$
\begin{aligned}
& \text { مناقشة القضايا المثيرة للجدل وكتابة الدراسات والمقالات حول المقاومة والاحتجاج على السلطة الحاكمة ، والقيام } \\
& \text { بعديد من الاحتجاجات والمظاهرات في القاهرة. يحتوى جمع بيانات البحث على مرحلتين، هما تعيين موضوع البحث }
\end{aligned}
$$

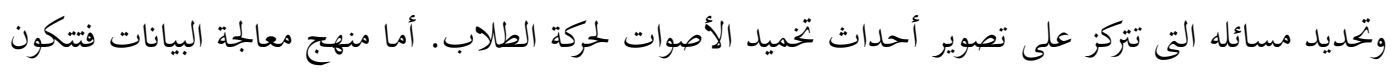

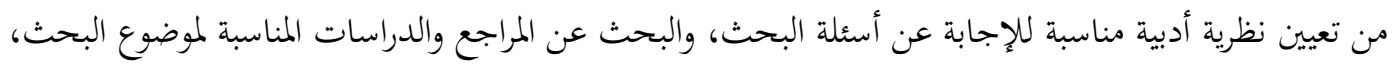

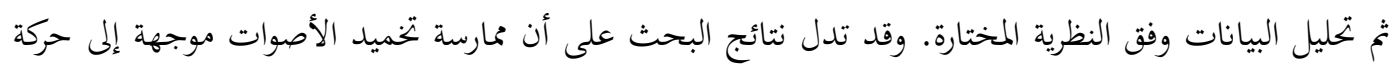

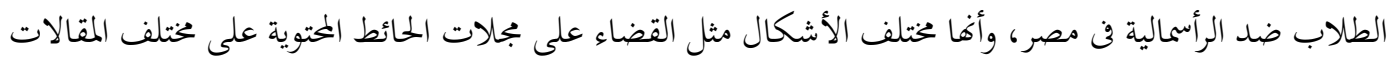




$$
\text { والاحتجاجات ضد السلطة الحاكمة والقبض على منشطي الحركة وتعذيبهم. وقد حدثت هذه المقاومة للتباين }
$$

\section{A. Pendahuluan}

Pasca penggulingan Jendral Muhammad Naguib, Gamal Abdul Nasser diangkat menjadi presiden pertama Mesir yang dipilih melalui pemilihan umum tahun 1953. Pada masa pemerintahannya, Nasser menghindari sistem multi-partai. Oleh karena itu, ia mendirikan Arab Socialist Union sebagai wadah aspirasi politik rakyat Mesir dan juga sebagai titik pusat kesadaraan bangsa Arab terhadap pentingnya Pan-Arabisme. Partai politik ini dilandasi paham sosialisme Arab yang ditafsirkan sebagai ideologi yang berorientasi pada cita-cita persatuan seluruh bangsa Arab (Sihbudi \& Et.all, 1995: 148). Hal ini disebabkan selama ini bangsa Arab terpecah ke dalam berbagai negara di kawasan Timur Tengah. Di kalangan masyarakat Mesir sendiri, ideologi sosialisme ini dianggap sebagai bentuk populisme yang diaplikasikan dengan kebijakan pemerintah demi kesejahteraan rakyat termasuk bidang pendidikan.

Pada saat itu pendidikan tidak lagi hanya untuk masyarakat menengah ke atas, tetapi juga untuk seluruh kalangan rakyat Mesir tanpa melihat perbedaan strata sosial dan gender. Faksh (2005: 45) mencatat bahwa pada tahun 1952 hanya 45 persen anak usia sekolah dasar yang bersekolah. Pada tahun 1960, proporsi tersebut meningkat menjadi 65 persen. Peningkatan ini juga terjadi di jenjang perguruan tinggi melalui demokratisasi pendidikan. Pemerintah membuka lebar kesempatan bagi pemuda-pemudi yang memiliki keinginan besar melanjutkan pendidikan di perguruan tinggi dengan membuka universitas baru dan melakukan modernisasi universitas yang sudah ada sebelumnya. Adanya interaksi dengan pelajar asing dan fasilitas pembelajaran yang memadai menjadikan para pelajar membaca buku-buku dan mendiskusikan pemikiran-pemikiran modern Barat sehingga terbentuklah golongan terpelajar yang sadar terhadap urgensi politik bagi kepentingan bangsa. Kesadaran ini direalisasikan dalam bentuk pergerakan politik yang mendukung cita-cita Nasserisme. Hal ini menciptakan hubungan simbiosis antara pemerintah Gamal Abdul Nasser dengan para mahasiswa.

Setelah rezim Nasser berakhir, Mesir dipimpin oleh Anwar Sadat yang memberlakukan kebijakan multi-partai. Pada rezim ini, muncul beberapa partai politik dengan berbagai ideologi dan kepentingan. Akan tetapi, National Democratic Party adalah partai yang memiliki kendali kekuatan yang besar. Sadat mulai membersihkan Parlemen Mesir dari orang-orang sayap kiri, yaitu orang-orang berhaluan sosialis dan pro kepada Uni Soviet (Hobbs, 2007: 65). Mesir mulai membuka hubungan kerjasama dengan Amerika Serikat yang berhaluan kapitalis dengan menerapkan kebijakan ekonomi Infitāch (Pintu Terbuka). Kebijakan ini memberikan kemudahan bagi para investor asing untuk berinvestasi di Mesir sehingga Bank-bank dan perusahaan-perusahaan Amerika membuka kantor cabang. Di sisi lain, kebijakan politik ini berdampak buruk bagi kaum tani dan buruh. Pembayaran hasil panen merosot dan mereka juga mengalami kesulitan mengakses layanan koperasi pedesaan, termasuk mendapatkan layanan kesehatan. Bagi para petani Infitāch menandakan berakhirnya reformasi tanah (Goldschmidt, 2008: 198).

$$
\text { Sadat dianggap gagal }
$$

menyejahterakan rakyat miskin karena penerapan kebijakan ekonomi liberal. Mahasiswa sebagai kaum intelek muda mulai menentang dan mencabut dukungan 
terhadap pemerintahan Sadat. Kelompok berpendidikan menyatakan tidak mendukung rezim tersebut, dan dengan memanfaatkan kebebasan politik, aktivisme politik mahasiswa oposisi memperoleh momentumnya (Erlich, 1989: 197). Pertentangan antara mahasiswa dan pemerintahan Sadat semakin tajam dengan penandatanganan perjanjian damai antara Arab dengan Israel yang dianggap hanya sebagai alat bagi terciptanya hubungan erat antara pemerintah Sadat dengan Amerika Serikat (Arafat, 2009: 9).

Aksi protes dan demo mahasiswa mulai marak terjadi di jalan-jalan protokol kota Kairo. Mereka menuntut pencabutan kesepakatan Mesir atas resolusi Amerika Serikat dan sistem ekonomi kapitalis yang mulai mencengkram Mesir. Sadat tidak tinggal diam, ia memerintahkan menteri Pertahanan Mesir untuk menurunkan pasukan militer dan polisi yang bergerak masuk ke kampus-kampus di Kairo dan menangkap para mahasiswa yang terlibat dalam demonstrasi. Sejak saat itu terjadi penangkapan para aktivis mahasiswa, bahkan beberapa universitas ditutup.

Pembungkaman terhadap aspirasi masyarakat ini terus berlanjut hingga masa kepemimpinan Husni Mubarak. Hal ini disebabkan kesamaan pandangan politik antara Sadat dan Mubarak. Mubarak juga memberlakukan sistem multi partai yang tetap didominasi oleh National Democratic Party (NDP) yang mendapat dukungan besar dari kaum borjuis Mesir, sehingga kursi parlemen Mesir diisi oleh para tuan tanah dan pengusaha (King, 2009: 93-94). Masyarakat golongan menengah ke bawah dipaksa untuk memilih NDP saat pemilu walaupun tidak sesuai dengan keinginan mereka.

Karya sastra sebagai cerminan langsung dari sebuah fenomena sosial, merefleksikan fenomena pembungkaman aspirasi pergerakan mahasiswa tersebut. Salah satu karya sastra yang memaparkan fenomena tersebut adalah sebuah novel berjudul Faraj. Novel ini menceritakan kondisi pergerakan mahasiswa Mesir yang mulai terbentuk dengan adanya modernisasi sistem pendidikan. Di dalam novel diceritakan bagaimana para mahasiswa melontarkan kritik menentang pemerintah melalui tulisan maupun aksi demo di jantung kota Kairo hingga berujung pada penggeledahan dan penangkapan, tidak ketinggalan pula gambaran tentang penganiayaan aparat Mesir terhadap mahasiswa, mulai pemukulan dengan tongkat hingga penusukan.

Untuk menampilkan masyarakat dalam teks sastra yang merupakan gambaran masyarakat riil sekaligus mengetahui pandangan dunia pengarang, maka artikel ini menggunakan teori strukturalisme genetik. Masyarakat dalam karya sastra diasumsikan sebagai salah satu bentuk unsur dari struktur karya sastra yang merupakan refleksi dari struktur masyarakat riil. Hal ini dikarenakan sebuah karya sastra tidak lahir dari kekosongan. Menurut Goldmann (1967: 493) tinjauan umum pertama dalam pemikiran seorang strukturalis genetik berdasarkan ilmu Humaniora, tidak berasal dari sesuatu yang kosong, tetapi dari sesuatu yang terdapat dalam masyarakat. Oleh karena itu penelitian ini, memanfaatkan pendekatan strukturalisme genetik untuk melihat pembungkaman terhadap pergerakan mahasiswa anti kapitalisme dalam masyarakat nyata dan juga dalam masyarakat karya sastra.

Pendekatan ini diyakini sebagai penataan struktur pemikiran pengarang sebagai subjek yang terbangun karena adanya interaksi sosial antara pengarang sebagai bagian dari anggota masyarakat dengan situasi sosial tertentu. Interaksi yang terjadi tersebut menghantarkan manusia pada permasalahan-permasalahan yang harus diselesaikan (Goldmann, 1973: 112). Adapun sastrawan tidak dianggap sebagai individu, tetapi merupakan bagian dari masyarakat kolektif yang mewakili perasaan, pemikiran, dan perilaku kelompok masyarakat tertentu. Oleh karena itu, pandangan dunia yang terdapat dalam karya seorang sastrawan merupakan pandangan dunia masyarakat kolektif, sesuai yang dirumuskan oleh Goldmann (2013: 17).

Dengan demikian, sebuah karya merupakan pencapaian kolektif melalui 
kesadaran individual si pencipta, sebuah pencapaian yang mengungkapkan kepada kelompok tersebut sesuatu yang sedang bergerak tanpa ia sadari, di dalam ide, perasaan, dan perilaku (Goldmann, 1973: 115). Sebagai bagian dari masyarakat kolektif, maka riwayat hidup dan psikologis pengarang tidak dapat menjadi acuan yang tepat untuk membedah asalusul kelahiran karya-karyanya (Goldmann, 1967: 497). Fenomena masyarakat yang direfleksikan oleh sastrawan dalam sebuah karya sastra ini tentu saja tidak lepas dari pengaruh sosial dan imajinasi seorang sastrawan sehingga menyebabkan distorsi (Goldmann, 1980: 40).

Dalam penelitian ini, pandangan dunia Radwa Ashour tentang pembungkaman pergerakan mahasiswa Mesir diangkat melalui peristiwa-peristiwa konkret pada rezim Presiden Gamal Abdul Nasser hingga rezim Presiden Husni Mubarak. Peristiwa-peristiwa tersebut dianggap sebagai peristiwa yang menjadi latar belakang penciptaan novel Faraj dan mengandung pandangan dunia Radwa Ashour sebagai bagian dari masyarakat kolektif.

\section{B. Hasil dan Pembahasan}

Dari aspek-aspek yang dibahas di dalam penelitian ini, sedikitnya terdapat tiga penelitian terdahulu yang menjadi tinjauan Pustaka, yaitu (a) aspek politik. Aspek ini dibahas dalam sebuah laporan yang berjudul The Concequences of the Introduction and Spread of Modern Education oleh Mahmud A. Faksh pada tahun 2005 (Faskh 2005). Tulisan ini mengemukakan tentang peningkatan taraf hidup dan ekonomi Mesir pada rezim Gamal Abdul Nasser. Salah satu sektor yang mendapatkan perhatian besar adalah sektor pendidikan. Pembebasan biaya pendidikan mendorong para pemuda maupun pemudi Mesir untuk belajar hingga perguruan tinggi. Salah satu dari hal ini adalah kesenjangan antara kaum terpelajar dan kaum tidak terpelajar Mesir dalam hal upah pekerjaan. Di samping itu, peningkatan taraf pendidikan Mesir ini diikuti dengan kampanye Pan Arabisme di kampus-kampus yang menyebabkan para pelajar menyadari peran mereka dalam ranah politik negara. (b) aspek sejarah. Sejarah awal terbentuknya pergerakan mahasiswa Mesir dan hubungannya dengan pemerintahan yang berkuasa. Topik ini dibicarakan dalam sebuah disertasi berjudul Student Politics in Egypt 1922-1952 yang ditulis oleh Christina W. Michelmore pada tahun 1983 (Michelmore 1983). Disertasi ini membahas tentang pergerakan politik mahasiswa Mesir sebelum terjadinya reovolusi Mesir 1952. Sebelum masa revolusi tersebut, pergerakan politik mahasiswa pun sudah gencar dilakukan untuk memprotes pemerintahan monarki Mesir yang korup dan hanya menjadi pemerintahan boneka Inggris. (c) aspek sosial. Tulisan yang menyinggung topik ini adalah buku yang berjudul Nasser and His Generation yang ditulis oleh P.J Vatikiotis pada tahun 1978 (Vatikiotis 1978). Buku ini berisi tentang rezim Gamal Abdul Nasser yang membuka lebar kesempatan masyarakat muda Mesir untuk mengenyam pendidikan hingga pendidikan tinggi. Hal ini dilakukan Nasser dalam rangka menggalangkan paham PanArabisme dan Sosialisme Arab.

Novel Faraj berisikan pandangan dunia Radwa Ashour sebagai bagian dari kelompok masyarakat yang mengalami pembungkaman oleh pemerintah Mesir pada saat itu. Ada tiga pandangan yang terdapat dalam novel ini, mengacu pada Strukturalisme Genetik Goldmann (Goldmann, 1967: 495) yaitu faktor terjadinya perlawanan gerakan mahasiswa, bentuk perlawanan yang dilakukan, dan pembungkaman terhadap perlawanan mahasiswa itu sendiri.

\section{Faktor Perlawanan Mahasiswa}

Menurut pandangan dunia Radwa Ashour, ada tiga faktor penyebab perlawanan gerakan mahasiswa terhadap pemerintah Mesir, yaitu perubahan pola pikir masyarakat, pengaruh pemberontakan mahasiswa Prancis pada Mei 1968, dan kebijakan politik pemerintah Mesir.

\section{Perubahan Pola Pikir Masyarakat}

Pasca revolusi 1952, Mesir dipimpin oleh seorang pemimpin yang berhaluan 
sosialisme. Pemerintahan tersebut memiliki cita-cita besar bagi bangsa Arab, khususnya masyarakat Mesir, melalui ideologi yang dikenal dengan istilah Nasserisme. Pemerintahan sosialisme dianggap menarik bagi masyarakat luas karena berhasil memainkan peran sebagai harapan dan penyelamat bagi masyarakat Mesir maupun bangsa Arab secara keseluruhan. Dalam novel Faraj, pemerintahan tersebut diwakili dengan karakter Gamal Abdul Nasser sebagai sosok sentral di tengah masyarakat.

و كان اسم عبد الناصر وصوته و صورته تتردد على

مدار الساعات كل يوم، تتغنى به أغنيات أحبها

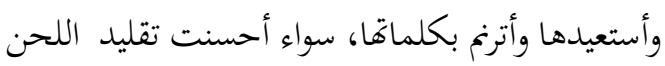

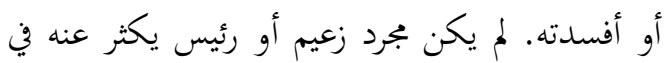

البيت والشارع والمدرسة، بل كان يسرى ببساطة في

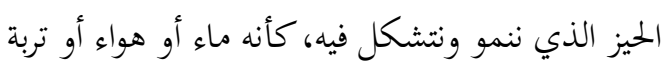

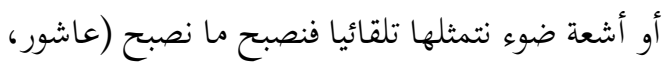

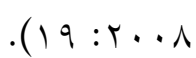

"Nama Abdul Nasser, suara, dan juga gambarnya bergema sepanjang hari dan setiap saat, selalu dilantunkan dalam lagulagu yang aku sukai dan sering aku nyanyikan lirik-liriknya, baik saat aku pandai menirukan irama musiknya atau saat aku tidak pandai. Abdul Nasser tidak hanya sang pemimpin dan ketua yang sering dibicarakan di rumah, di jalanan, maupun di sekolah, tetapi juga namanya mudah ditemukan di ruangan yang merupakan tempat kami tumbuh dan berkembang, seakan-akan ia adalah air, udara, tanah, ataupun sinar yang sama dengan apa yang kami gambarkan" (Ashour, 2008: 19).

Di bawah kepemimpinannya, ia mampu menyejahterakan rakyatnya. Salah satu kesejahteraan itu tampak dalam bidang pendidikan. Masyarakat mendapatkan pendidikan yang layak bahkan mereka dapat melanjutkan pendidikan hingga ke jenjang doktoral di luar negeri (Hartman 2015).

بابا أستاذ في الجامعة وحصل على الدكتوراه، وكان

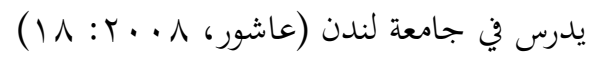

"Papa adalah seorang profesor di universitas. Ia telah menerima gelar doktor dan mengajar di Universitas London" (Ashour, 2008: 18).

Peningkatan taraf pendidikan tersebut menjadikan masyarakat memiliki minat membaca. Mereka membaca karyakarya penulis besar, baik karya barat maupun karya dari negara-negara Timur Tengah. Mereka mengenal sederet penulis besar yang memiliki perhatian terhadap kritik sosial seperti Victor Hugo, Honorè de Balzac, Gustave Flaubert, Emile Zola, Emily Dickens, hingga Taufik al-Hakim. Hal ini sebagaimana karya-karya Victor Hugo yang mengkritik pemerintahan tirani Napoleon Bonaparte III atau karya Taufik al-Hakim yang merupakan respon terhadap peristiwa sosial politik Mesir seperti revolusi Mesir 1952.

Fenomena tersebut digambarkan Radwa Ashour dalam novel Faraj saat salah seorang tokoh imajiner yaitu ibu dari Nida yang mengirimkan berbagai macam buku yang berkaitan dengan sejarah, sosial, dan politik dari Perancis. Oleh karena itu, ia memiliki antusiasme membaca yang tinggi. Ia menyukai novel-novel klasik, novel-novel Mesir, dan novel-novel Aljazair.

$$
\begin{aligned}
& \text { أقرأ روايات وكتبا في التاريخ وين الإجتماع والسياسة } \\
& \text { (أرسلت أمي كتابا عن ثورة شجا، بدأت في قراءته ما } \\
& \text { إن استلمته بعد عودتي من المدرسة وانتهيت منه قبل } \\
& \text { موعد المدرسة بنصف ساعة. يومها غفوات مرتين أثناء } \\
& \text { الدرس). أقرأ كل ما تقع عليه يدي من كتابات. كانت } \\
& \text { الروايات هي الأحب إلى نفسي، تطربني اللغة وقدرتا }
\end{aligned}
$$

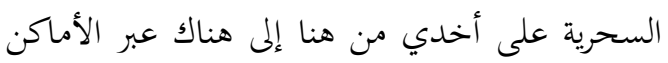

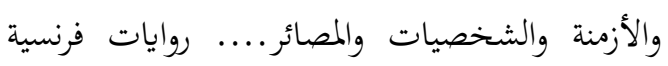

$$
\begin{aligned}
& \text { رومانية وواقعية من القرن التاسع عشر لهوجو وشاتوبريان }
\end{aligned}
$$

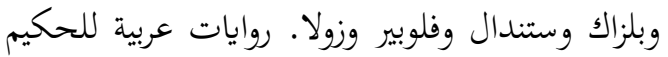

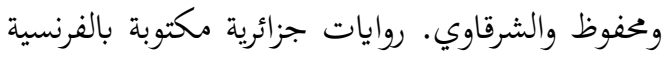

$$
\begin{aligned}
& \text { لكاتب ياسين ومحمد ديب. روايات إنجليزية مترجمة إلى }
\end{aligned}
$$




$$
\begin{aligned}
& \text { الفرنسية أو العربية لديكنز والأختين شارلوت وإيميلي }
\end{aligned}
$$

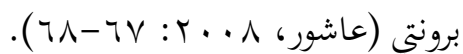

"Aku membaca novel-novel dan bukubuku sejarah, sosial dan politik (Ibuku mengirimkan buku-buku tentang Revolusi 68. Aku memulai membacanya setelah pulang sekolah dan menyelesaikannya sebelum berangkat sekolah, selama setengah jam dan dua kali dalam sehari di tengah-tengah pelajaran). Aku membaca semua buku yang ada di tanganku. Novel merupakan hal yang paling aku sukai. Bahasa dan kemampuan ajaib novel-novel itu membuat diriku bahagia membawaku dari sini ke sana menyebrangi berbagai tempat, zaman, kepribadian, dan takdir.... Novel-novel Perancis dan Romawi abad ke-19 karya Hugo, Chateaubriand, Balzac, Stendhal, Flaubert, dan Zola. Novel-novel Arab karya Hakim, Mahfuzh, dan asySyarqawi. Novel-novel Aljazair yang ditulis dalam bahasa Perancis karya Katib Yasin dan Muhammad Dib. Novel-novel Inggris yang diterjemahkan ke dalam bahasa Perancis dan Arab karya Dickens dan Charlotte serta Emily Bronte bersaudara" (Ashour, 2008: 67-68).

Tokoh imajiner Nida Abdul Qadir dalam kutipan di atas menggambarkan ketertarikan anak-anak muda Mesir terhadap permasalahan sosial, politik, dan juga perlawanan. Misalnya karya-karya Victor Hugo yang menampilkan kekacauan politik pasca kekuasaan Napoleon Bonaparte dan persitiwa revolusi Prancis. Contoh lainnya adalah karya-karya Muhammad Dib yang memotret perjuangan bangsa Aljazair mencapai kemerdekaan. Dengan reformasi dunia pendidikan di Mesir dan juga kemudahan untuk mengakses berbagai buku, anakanak muda khususnya mahasiswa Mesir memiliki pola pikir kirtis ketika menanggapi isu tertentu.

\section{Pemberontakan Mahasiswa Prancis tahun 1968}

Faktor kedua adalah peristiwa pemberontakan mahasiswa yang terjadi di Perancis pada tahun 1968. Mereka merupakan pergerakan mahasiswa yang menganut paham Stalinisme. Paham ini berpendapat bahwa selama kaum borjuis belum dikalahkan dan selama kekayaannya belum disita, proletar harus memiliki kekuatan militer untuk menangkis serangan kontra revolusioner dari Borjuis. Tanpa hal itu, kaum kapitalis akan terus membeli tenaga kerja kaum proletar. Bagi Stalin, untuk mencapai masyarakat sosialis diperlukan revolusi sosial dan revolusi sosial harus dimulai dengan diktator proletariat, yaitu proletariat harus merebut kekuasaan politik sebagai alat untuk mencabut hak milik kaum borjuis (Syam, 2007: 201).

Pemberontakan terjadi pada tanggal 22 Maret di Universitas Nanterre saat sekelompok mahasiswa menyerbu kantor Rektorat untuk memprotes penangkapan beberapa aktivis yang terlibat dalam gerakan anti-Perang Vietnam. Pemberontakan kembali terjadi di halaman universitas pada tanggal 3 Mei. Sekitar sore hari, satu regu polisi berhelm dan bersenjatakan tongkat karet serta tameng berbaris memasuki lapangan universitas dan mengepung para demonstran hingga terjadi bentrokan antara dua kelompok tersebut. Pada akhirnya, sekelompok mahasiswa ditahan dan aktifitas kampus dihentikan (Anon n.d.).

Dalam novel Faraj, pemberontakan mahasiswa ini terjadi beberapa minggu sebelum Nida Abdul Qadir datang mengunjungi ibunya di Perancis. Nida Abdul Qadir adalah tokoh yang merepresentasikan aktivis mahasiswa, merasa antusias mendengarkan kisah di balik kerusuhan besar tersebut sebagaimana kutipan berikut:

$$
\begin{aligned}
& \text { كان جيرار يهكي لي عن مظاهرات الطلبة بدءا من Tr } \\
& \text { مارس في نانتير حيث اقتحم ثمانية طلاب مكتب العميد } \\
& \text { احتجاجا علي اعتقال ستة من زملائهم عقابا على } \\
& \text { نشاطتهم في لجنة تناهض الحرب الفييتامية. تقرر تقديم } \\
& \text { هؤلاء الطلبة الثمانية بعد شهر، لمجلس تأذيب }
\end{aligned}
$$

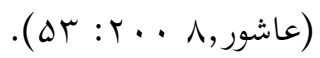

"Gerard memberitahuku tentang demonstrasi mahasiswa yang dimulai dari tanggal 22 Maret di Nanterre, di mana 
delapan orang mahasiswa menyerbu kantor Dekan untuk memprotes penangkapan enam rekan mereka akibat aksi dalam komite oposisi perang Vietnam. Dewan disipliner memutuskan untuk memenuhi tuntutan delapan mahasiswa tersebut setelah satu bulan" (Ashour, 2008: 53).

Permasalahan awal dari pemberontakan mahasiswa ini adalah akibat dari penangkapan beberapa aktifis yang memprotes keterlibatan pemerintah Perancis dalam perang Vietnam yang tidak berkesudahan. Penangkapan tersebut berujung demonstrasi besar-besaran di depan Universitas Nanttere. Jumlah demonstran semakin bertambah dan menuntut Charles de Gaulle untuk turun dari tampuk kepemimpinan. Polisi anti hura-hara mengepung para demonstran dan mulai menangkap mereka. Persitiwa ini memicu gelombang yang lebih besar lagi sehingga pemerintah menutup Universtas Nanterre.

\section{Kebijakan Pro Kapitalisme}

Pasca pemerintahan Gamal Abdul Nasser, pemerintahan selanjutnya mulai membuka hubungan dengan Amerika yang merupakan negara penganut paham kapitalisme. Hubungan tersebut menimbulkan intervensi Amerika terhadap urusan dalam dan luar negeri Mesir. Landasan sosialisme Arab mulai terganti dengan kapitalisme. Anggota parlemen pro sosialis dikeluarkan, dan Mesir mulai menerapkan kebijakan Infitāch sebagaimana yang telah dipaparkan sebelumnya.

Liberalisasi ekonomi dan pro politik Barat menenggelamkan kelas menengah dalam kemiskinan. Masyarakat Mesir menjadi masyarakat konsumtif seperti halnya masyarakat Barat. Namun, yang membedakan adalah masyarakat Mesir menikmati barang-barang mewah yang bukan hasil produksi sendiri. Kelas pebisnis mulai memonopoli modal dan menerapkan sistem nilai baru dengan keuntungan cepat, secara arogan dan penuh tipuan. Masyarakat Mesir mulai bermigrasi menuju negara-negara Teluk, terutama negara-negara penghasil minyak untuk mencari pekerjaan dan memenuhi tuntutan hidup (Ashour, 2008a: 132).

Hubungan antara Mesir dengan Amerika ini berlanjut kepada usaha perundingan damai Mesir dengan Israel. Pihak Mesir memenuhi undangan perdana menteri Israel. Kunjungan ini memunculkan protes di kalangan bangsa Arab. Kalangan gerilyawan Palestina yang menganut paham Marxisme menyatakan bahwa mereka tidak akan mengakui eksistensi negara Israel dan tidak akan pernah berdamai (Thayib \& Sadaruwan, 1981: 73).

Di Mesir sendiri, usaha perdamaian tersebut membuat kondisi Mesir kacau. Harga melonjak dan persediaan bahan pangan merosot. Buruh dan mahasiswa pun melakukan demonstrasi, yang menyebabkan beberapa tokoh buruh dan mahasiswa ditahan (Thayib \& Sadaruwan, 1981: 62-63). Novel Faraj memaparkan peristiwa ini melalui gambaran diskusidiskusi bertema politik, sosial, dan ekonomi, khususnya usaha perjanjian damai antara Mesir dengan Israel, yang digelar oleh organisasi politik kampus.

$$
\begin{aligned}
& \text { نناقش الأوضاع الإقتصادية والسياسية والإجتماعية. }
\end{aligned}
$$

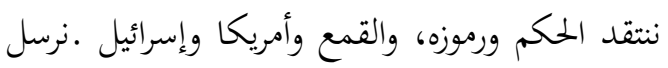

$$
\begin{aligned}
& \text { وفودا إلي مجلس الشعب والنقابات ونستقبل وفودا منها، } \\
& \text { و تأتينا برقيات مساندة وتأييد ونطالب بحضور رئيس }
\end{aligned}
$$

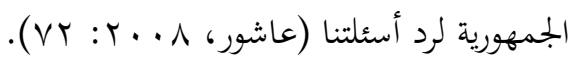

"Kami membahas situasi ekonomi, politik, dan sosial. Kami mengkritik pemerintahan dan kebijakannya, represi, Amerika, serta Israel. Kami mengirimkan delegasi ke parlemen dan perserikatan buruh dan menerima delegasi mereka. Mereka datang dengan membawa dukungan dan kami meminta kehadiran presiden untuk menjawab pertanyaan-pertanyaan kami" (Ashour, 2008b: 72).

\section{Bentuk Perlawanan Mahasiswa}

Adapun bentuk perlawanan pergerakan mahasiswa dalam pandangan dunia Radwa Ashour terdiri dari 1) kegiatan simposium, seminar, maupun kelompok diskusi antar mahasiswa, 2) penulisan artikel yang mengkritik 
pemerintah, 3) aksi unjuk rasa

$\begin{array}{ccr}\text { Kegiatan Simposium, Seminar, dan Diskusi } \\ \text { Bentuk } & \text { awal dari } & \text { perlawanan } \\ \text { pergerakan } & \text { mahasiswa } & \text { terhadap }\end{array}$ pemerintah berupa kegiatan simposium, seminar, maupun kelompok diskusi. Melalui kegiatan tersebut, mereka memperoleh pemikiran-pemikiran baru yang berkaitan dengan ranah politik dalam negeri Mesir.

$$
\begin{aligned}
& \text { في الجامعة، أتحرك كالنحلة. أطير من كلية الهندسة إلى } \\
& \text { كلية الآداب، ومن الآداب إلى كلية الإقتصاد ثم أعود } \\
& \text { طائرة إلى كلية الهندسة ثم أطير ثانية إلى الحرم } \\
& \text { الجامعي.أحضر مؤتمرات وندوات وحلقات نقاشية. }
\end{aligned}
$$

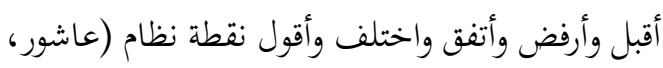

$$
\begin{aligned}
& .(79: \% \cdots 1
\end{aligned}
$$

"Di universitas, aku bergerak seperti lebah. Terbang dari Fakultas Teknik ke Fakultas Sastra, dari Fakultas Sastra ke Fakultas Ekonomi, kembali ke Fakultas Teknik kemudian terbang lagi ke konferensi kampus. Aku menghadiri simposium, seminar, dan pertemuan diskusi. Aku menerima, menolak, berselisih, dan mengatakan titik peraturan" (Ashour, 2008b: 69).

Tokoh Nida Abdul Qadir sebagai repesentatif riil seorang aktivis menghadirkan gambaran antusiasme akan isu-isu politik Mesir dan bentuk perlawanan dari kebijakan politik yang dirasa merugikan masyarakat Mesir. Salah satu diskusi yang disorot novel Faraj adalah diskusi mahasiswa dengan anggota parlemen terkait dengan kebijakan kerjasama pemerintah Mesir dengan Amerika beserta sekutunya yaitu Israel.

$$
\begin{aligned}
& \text { تلازمنا في القاعة مع آلاف الطلاب طوال سبعة أيام. } \\
& \text { نناقش الأوضاع الإقتصادية والسياسية والإجتماعية. } \\
& \text { ننتقد الحكم ورموزه، والقمع وأمريكا وإسرائيل. نرفع يدنا } \\
& \text { لنصوت مع، أو نصوت ضد، أو نقول نقطة نظام. } \\
& \text { نختلف ونتتفق ونساهم في صياغة بيان نشارك في الحوار } \\
& \text { والسندويتشات والغضب والقلق والزهو بالانتماء لجسد }
\end{aligned}
$$

$$
\begin{aligned}
& \text { طلابي لجنة عليا من اختياره، يوقع بياناته بعبارة ((كل } \\
& \text { الديمقراطية للشعب و كل التفاني للوطن)). نرسل وفودا } \\
& \text { إلي بجلس الشعب و النقابات ونستقبل وفودا منها، }
\end{aligned}
$$

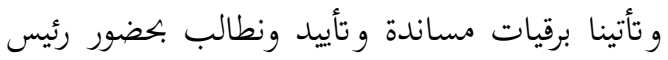

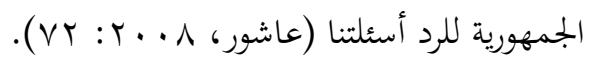

"Kami ikut berkumpul dengan ribuan mahasiswa selama tujuh hari. Kami membahas situasi ekonomi, politik, dan sosial. Kami mengkritik pemerintahan dan kebijakannya, represi, Amerika, serta Israel. Kami mengangkat tangan kami untuk bersuara pro atau bersuara kontra serta mengatakan tentang titik aturan. Kami berselisih, dan berkontribusi penyusunan petisi. Kami berbagi percakapan, Sandwich, kemarahan, kecemasan, dan kebanggaan terhadap lembaga kemahasiswaan yang memiliki sebuah komite tertinggi dari pemilihannya. Komite tersebut menandatangani pernyataan dengan frase (Seluruh demokrasi untuk rakyat dan seluruh pengabdian untuk tanah air). Kami mengirimkan delegasi ke parlemen dan perserikatan buruh dan menerima delegasi mereka. Mereka datang dengan membawa dukungan dan kami meminta kehadiran presiden untuk menjawab berbagai pertanyaan kami" (Ashour, 2008b: 72).

Pada saat kerjasama antara Mesir dengan Amerika dan Israel dibuka, para mahasiswa melakukan aksi berkumpul di dalam aula kampus. Di sana mereka membicarakan hal-hal mengenai ekonomi, politik, dan sosial. Mereka juga mengkritik kebijakan pemerintah, termasuk hubungan Mesir dengan Amerika serta Israel. Aksi tersebut membuahkan kesepakatan atas demokrasi untuk rakyat dan pengabdian bagi tanah air. Selain hal itu, para mahasiwa bersepakat mengirimkan delegasi mereka ke parlemen dan perserikatan buruh. Mereka meminta kehadiran presiden Mesir untuk menjawab pertanyaan-pertanyaan mereka seputar permasalahan kehidupan sosial, ekonomi, dan politik.

\section{Penulisan Artikel}


Perlawanan mahasiswa juga terlihat dari tulisan yang dipublikasi melalui majalah dinding kampus. Artikel yang dianggap mengkritik pemerintah tersebut berakibat pada penahanan tiga orang mahasiswa Fakultas Kedokteran Universitas Kairo atas tuduhan sebagai provokator bagi organisasi politik mahasiswa lainnya. Penangkapan mahasiswa semakin massif hingga 52 orang. Hal tersebut menyulut aksi mahasiswa lainnya, mereka bekerjasama dengan perserikatan buruh dan menuntut pembebasan para mahasiswa yang dipenjarakan. Mereka melakukan aksi duduk di aula Universitas Kairo, diikuti pula oleh para mahasiswa Fakultas Teknik dan Fakultas Kedokteran Universitas 'Ain Syams. Aksi ini kemudian pindah ke Istana Za'faran. Perlawanan ini diakhiri dengan penangkapan para aktivis mahasiswa tersebut.

$$
\begin{aligned}
& \text { كان عاما حافلا بمجريات مثيرة بدأت بتقديم ثلاثة } \\
& \text { زماء من كلية الطب إلي مجلس تأديب بتهمة الكتابة }
\end{aligned}
$$

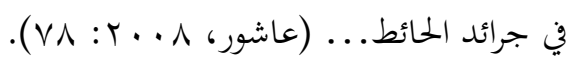

"Tahun ini adalah tahun yang penuh dengan kekhawatiran dengan adanya pengiriman tiga teman dari Fakultas Kedokteran ke dewan disipliner atas tuduhan tulisan di majalah dinding..." (Ashour, 2008b: 78).

Kutipan di atas menggambarkan bahwa tulisan adalah senjata yang menakutkan bagi pihak tertentu karena tulisan dapat mengubah cara pandang dan pola pikir. Oleh karena itu, banyak sekali penulis yang dijebloskan ke dalam penjara akibat dari tulisan-tulisan mereka.

\section{Aksi Unjuk Rasa}

Bentuk perlawanan yang ketiga adalah aksi unjuk rasa yang dilakukan di jantung kota maupun di depan kantor Kedutaan Besar Tertentu. Novel Faraj memaparkan hal tersebut melalui aksi duduk di aula Universitas Kairo yang dilakukan mahasiswa dan mahasiswi Fakultas teknik dan Fakultas Kedokteran. Kemudian mereka berjalan menuju Istana Za'faran yang merupakan kantor pusat administrasi Universitasn Ain Syams.

$$
\begin{aligned}
& \text { فبدأنا ناشطا مكثفا للمطالبة بالإفراج عنهم، ولتأكيد } \\
& \text { أن حملات الاعتقال لن تحول بيننا وبين مواصلة الإعلان } \\
& \text { عن مطالبنا. عقدنا مؤتمرات، أصدرنا بيانات، اتصلنا } \\
& \text { بنقابات، و اعتصمنا بجددا في قاعة الاحتفالات بجامعة } \\
& \text { القاهرة. و اعتصم زملاء و زميلات لنا في كلية الهندسة }
\end{aligned}
$$

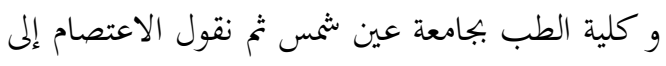

$$
\begin{aligned}
& \text { قصر الزعفران، مقر إدارة جامعة عين شنمس. ثم حمله }
\end{aligned}
$$

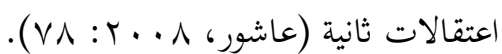

"Kami memulai aksi intensif untuk pembebasan mereka dan menegaskan bahwa penangkapan tidak beralih ke antara kami dan pihak yang melanjutkan pengumuman tentang tuntutan kami. Kami mengadakan konferensi, merilis data, menghubungi serikat buruh, dan melakukan aksi duduk di aula Universitas Kairo. Teman-teman putra maupun putri dari Fakultas Teknik dan Fakultas Kedokteran juga melakukan aksi duduk. Kemudian kami pindah ke Istana Za'faran yang merupakan pusat administrasi Universitas 'Ain Syams. Kemudian terjadilah penangkapan kedua" (Ashour, 2008b: 78).

Bentuk aksi unjuk rasa yang lainnya adalah aksi demo yang bermula di dalam lingkungan Universitas Kairo. Sebelum para demonstran keluar dari gerbang kampus, para petugas keamanan terlebih dahulu mengunci gerbang dan seluruh pintu masuk kampus. Mereka menutup akses jalan yang menghubungkan Universitas Kairo dengan kantor Kedutaan Besar Israel dan mengepung seluruh penjuru universitas. Hal tersebut membuat para mahasiswa peserta demonstrasi tidak dapat keluar dari dalam kampus mereka untuk melakukan aksi.

$$
\begin{aligned}
& \text { خرجت من بوابه الكلية فرأيت المئات من رجال الأمن } \\
& \text { بالخوذ والدروع يشكلون حائطا يغلق الطريق بين } \\
& \text { الجامعة والسكة المؤدية لتماثل غضة مصر والسفارة } \\
& \text { الإسرائيلية. ورأيت متظاهرين خارج الحرم يجبطون } \\
& \text { بقاعدة النصب التذكاري، ومتظاهرين آخرين أكثر }
\end{aligned}
$$


بكثير وراء البوابة، وكانت مغلقة. سرت بابتاه كلية الفنون التطبيقية لأدخل من أحد الأبواب الجانبية

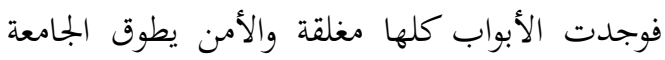

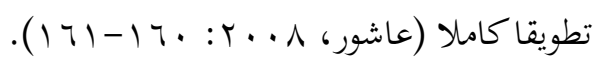

"Aku keluar dari gerbang kampus dan melihat ratusan petugas keamanan dengan helm dan perisai berbaris menutup jalan antara universitas dan jalan kereta mengarah ke Nahdhah Misr dan Kedutaan Besar Israel. Aku melihat para demonstran mengelilingi dasar monumen peringatan dan para demosntran lain yang lebih banyak berada di belakang gerbang yang terkunci. Aku berjalan ke arah Fakultas Seni Terapan untuk masuk ke salah satu pintu samping. Namun, aku menemukan semua pintu telah terkunci dan para petugas keamanan mengepung seluruh universitas" (Ashour, 2008b: 160-161).

Seorang mahasiswi di antara mereka memanjat gerbang kampus dan berteriak dengan suara yang lantang. Perbuatannya tersebut berhasil memprovokasi para mahasiswa lainnya. Mereka mengerumuni gerbang universitas dan berteriak. Para petugas keamanan melepaskan gas air mata kepada kerumunan mahasiswa tersebut. Namun, peringatan tersebut tidak menyurutkan langkah mereka sehingga gerbang universitas dapat dibuka dengan paksa. Setelah gerbang terbuka, para demonstran bergegas keluar. Mereka meneriakkan yel-yel mengejek pemerintah Mesir yang dianggap tidak memikirkan nasib saudara sebangsa mereka di tanah Palestina.

$$
\begin{aligned}
& \text { أمسك بالحجارة وألقي بها على الجنود الذين كانوا } \\
& \text { يلاحقوننا بالعصي حتى ونحن نغنتن بالغاز الذي } \\
& \text { أطلقوه. أهتف فلسطين عربية، وأركض، أقول يا حكومة بالنا }
\end{aligned}
$$

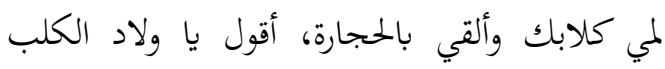

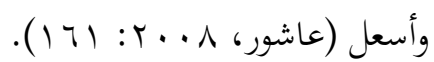

"Aku meraih batu dan melemparkannya kepada para tentara yang menganiaya kami dengan tongkat hingga kami tersedak gas yang mereka lemparkan. Aku berteriak 'Palestina adalah Arab', kemudian aku berjalan dan berkata 'Hai Pemerintah, kumpulkan kembali anjing-anjingmu' aku melempar batu dan berkata 'Wahai anakanak anjing dan aku terbatuk" (Ashour, 2008b: 161).

Aksi demo mahasiswa terjadi lagi pada saat pemerintah Mesir memutuskan berkoalisi dengan Amerika dan Inggris untuk menyerang Irak. Para mahasiswa berasumsi bahwa penyerangan tersebut bukan bertujuan untuk membebaskan masyarakat Irak dari cengkraman Saddam Husain. Penyerangan tersebut bertujuan untuk menjajah masyarakat Irak. Hal tersebut dikarenakan jatuhnya korban dari masyarakat sipil Irak akibat tembakan rudal dari kapal-kapal perang Amerika. Novel Faraj menggambarkan hal tersebut saat salah satu tokoh imajinernya menyaksikan konferensi pers yang dilakukan oleh Tommy Franks, komandan komando militer pusat Amerika.

$$
\begin{aligned}
& \text { رفعت صوت التلفزيون ورحت أتابع المؤنمر الصحفي } \\
& \text { الأول لتومى فرانكس قائد العمليات: يقول: (هذه حملة } \\
& \text { واسعة النطاق، لم سيبق لها مثيل، تتميز بالصدمة } \\
& \text { والمفاجئة والمرونة وإعمال قوة كاسحة. جنودنا يؤدون } \\
& \text { واجبهم بشكل رائع). رتل من المدرعات يقطع } \\
& \text { الصخراء. كرات هائلة من اللهب على خلفية من } \\
& \text { الدخان والنخيل. جنود أمريكيون على متن بارجة } \\
& \text { هائلة، يهللون مع إطلاق أول قذيفة من قذائف }
\end{aligned}
$$

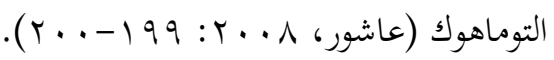

"Aku mengeraskan suara televisi dan mulai mengikuti konferensi pers pertama Tommy Franks, komandan komando operasi militer. Ia berkata: (Ini adalah kampanye besar-besaran yang belum pernah terjadi sebelumnya. Ditandai dengan kejutan, keleluasaan, dan kekuatan yang luar biasa. Pasukan kami menjalankan kewajiban mereka dengan luar biasa). Tank-tank berlapis baja melakukan konvoi di tengah gurun pasir. Bola api yang sangat besar terletak di belakang asap dan pohon Palm. Tentara Amerika yang berada di atas kapal perang yang sangat besar menyerang dan bersorak sorai menembakkan sebuah rudal Tomhawk" (Ashour, 2008b: 199-200). 
Para mahasiswa berusaha menerobos masuk ke dalam kantor Kedutaan Besar Amerika dan Inggris yang terletak di wilayah Garden City. Namun, usaha mereka dihalangi oleh petugas keamanan yang berjaga di sekitar kantor kedutaan tersebut. Petugas keamanan menghalau para demonstran ke Lapangan Tahrir dan membiarkan mereka berdemo meneriakkan tuntutan mereka.

بقينا في الميدان من الواحدة ظهرا حتى الحادية عشرة

مساء، تركنا الأمن نتظاهر في الميدان، ولم يتدخل إلا تلإ

عندما حاول البعض الوصول مجددا إلى السفارتين

الإنجلزية والأمريكية في جاردن سيتي... (عاشور،

( $(19 \cdot:$ : . . 1

"Kami menetap di lapangan dari jam satu siang hingga jam sebelas malam. Para petugas keamanan membiarkan kami berdemonstrasi di lapangan dan tidak mengganggu hingga saat sebagian mahasiswa mencoba mencapai kembali Kedutaan Besar Inggris dan Amerika di Garden City..." (Ashour, 2008b: 190).

\section{Bentuk Pembungkaman}

Pembungkaman

terhadap pergerakan mahasiswa yang terjadi berupa 1) penggeledahan dan penangkapan, 2) pemenjaraan, dan 3) kekerasan dan penganiayaan.

\section{Penggeledahan dan Penangkapan}

Perlawanan mahasiswa tersebut dapat dipatahkan oleh pemerintah dengan penggeledahan dan penangkapan. Aparat militer, kepolisian, maupun inteligen negara mendatangi kediaman para aktivis mahasiswa. Kediaman mereka digeledah dan mereka ditangkap.

$$
\begin{aligned}
& \text { فتح الباب. دخل رجلان في اللباس المدني يتبعهم ثلاثة } \\
& \text { رجال من العساكر أو المخبرين. وبقي عند الباب ثلاثة } \\
& \text { رجال بزي الشرطة يشرعون في أيديهم البنادق. فتشوا }
\end{aligned}
$$

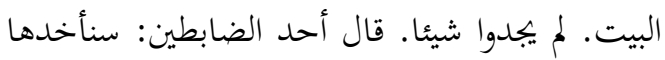

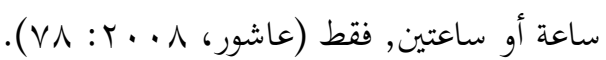

"Dia (ayah) membuka pintu. Kemudian masuklah dua orang pria berpakaian sipil diikuti dengan tiga orang inteligen. Tiga orang yang berseragam polisi dan memegang senjata di tangan mereka menetap di pintu. Mereka memeriksa rumah. Namun, tidak menemukan sesuatu. Salah seorang polisi berkata:

Saya akan membawanya (Nida Abdul Qadir) selama sejam atau dua jam saja" (Ashour, 2008b: 78).

\section{Pemenjaraan}

Para aktivis yang ditangkap kemudian dijebloskan ke dalam penjara khusus yang disebut Panopticon. Panopticon merupakan bangunan penjara berdisain bundar hasil pemikiran seorang filosof Inggris bernama Jeremy Bentham pada akhir abad ke-19. Disain tersebut digunakan untuk memisahkan setiap tahanan dan memudahkan pemantauan dengan jumlah sipir yang terbatas.

$$
\begin{aligned}
& \text { اقترح بنتام في تقرير بناء السجن بما يتيح فصل كل } \\
& \text { سجين علي حدة، ومراقبة السجناء من قبل حارس }
\end{aligned}
$$

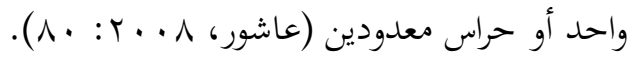

"Bentham memberikan saran dalam penentuan pembangunan penjara yang memungkinkan adanya pemisahan setiap tahanan dan kemudahan pemantauan oleh satu sipir atau beberapa sipir dengan jumlah terbatas" (Ashour, 2008b: 80).

Di dalam penjara tersebut, para mahasiswa maupun mahasiswi diinterogasi dengan berbagai macam pertanyaan. Setelah mengajukan pertanyaan tentang biodata masing-masing individu, interogasi tersebut dilanjutkan dengan pertanyaan seputar partisipasi mereka dalam kegiatan kemahasiswaan, tulisan-tulisan mereka, dan pembicaraan-pembicaraan yang terjadi dalam berbagai seminar maupun wawancara.

$$
\begin{aligned}
& \text { لكل بنت أو ولد ملف كامل يبدأ باسمه أو اسمها الثلاثي } \\
& \text { وأحيانا الرباعي، ومحل الإقامة والكلية والفرقة. يليها }
\end{aligned}
$$

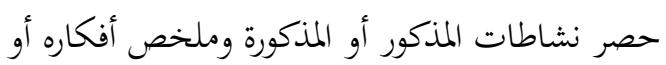

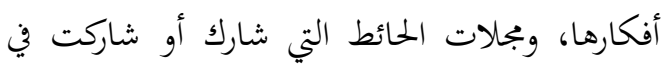

$$
\begin{aligned}
& \text { تحريرها، وأحيانا نص كلام قاله أو قالته في ندوة أو لقاء }
\end{aligned}
$$

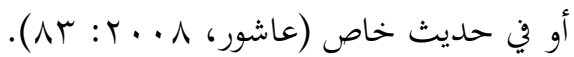


"Setiap anak perempuan dan laki-laki mempunyai sebuah berkas yang dimulai dengan nama mereka ketiga dan terkadang empat, tempat tinggal, kampus, serta kelompok gerakan. Diikuti dengan catatan kegiatan-kegiatan, ringkasan pemikiran, majalah-majalah dinding yang mereka ikuti dalam penyuntingannya, dan terkadang teks kata yang mereka ucapkan dalam sebuah seminar, pertemuan, serta wawancara ekslusif" (Ashour, 2008b: 83).

Novel Faraj menggambarkan peristiwa intrograsi ini melalui tokoh bernama Siham Sa'id ad-Din Shabri. Dalam interogasi tersebut, Siham menyatakan bahwa ia terlibat aktif dalam kegiatan-kegiatan aksi pergerakan mahasiswa yang melawan penindasan. Ia mengikuti persatuan mahasiswa dan ikut bergabung dalam perkumpulan relawan untuk kemerdekaan Palestina. Dalam hal kepenulisan, ia menulis berbagai artikel yang berisi kritikan terhadap pemerintah Mesir sebagai otoritas tertinggi atas tindakan represif dalam penyelesaian isu nasional.

$$
\begin{aligned}
& \text { نعم، شاركت في الاعتصام. شاركت في المسيرة. شاركت } \\
& \text { في المؤتمر. شاركت نشاط جماعة أنصار الثورة } \\
& \text { الفلسطينية. شاركت في الدعوة لإنشاء لجان للدفع عن } \\
& \text { الديمقراطية.نعم، انتقدت في مقالاتي السلطة لممارستها لتهاء } \\
& \text { القمعية وسياساتها الخاطئة في تناول القضايا الوطنية }
\end{aligned}
$$

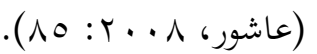

"Ya, aku ikut serta dalam aksi duduk. Aku mengikuti demonstrasi. Aku mengikuti konferensi. Aku mengikuti kegiatan perkumpulan relawan revolusi Palestina. Aku berpartisipasi dalam komite pembentukan demokrasi.

Ya, di dalam artikel-artikelku, aku mengkritik otoritas pemegang kebijakan atas tindakan represif dan salah dalam menangani isu-isu nasional" (Ashour, 2008b: 85).

\section{Kekerasan dan Penganiayaan}

Dalam aksi unjuk rasa, para mahasiswa tidak jarang mengalami kekerasan dan penganiayaan yang dilakukan oleh aparat kepolisian. Mereka memukuli para demonstran dengan tongkat, melepaskan tembakan gas air mata, dan menyiram air dengan bantuan mobil pemadam kebakaran.

$$
\begin{aligned}
& \text { ساعتها دارت معارك حامية بالعصي والغاز المسيل } \\
& \text { للدموع ورشاشات سيارات المطافئ من جانب دانب }
\end{aligned}
$$

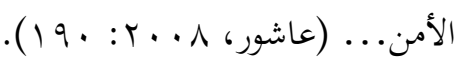

"Bahkan terjadi pertempuran sengit dengan menggunakan tongkat, gas air mata, dan semprotan air dari mobil-mobil pemadam kebakaran..." (Ashour, 2008b: 190).

Tidak hanya dianiaya oleh aparat, para mahasiswa juga diserang oleh sekelompok preman yang membawa tongkat, rantai, dan juga pisau. Mereka dipukul dan ditendang sehingga mengalami cedera dan dilarikan ke dalam kampus Fakultas Teknik. Polisi anti huru hara ikut memukuli, menendang, dan menyemprot mereka dengan gas air mata. Seorang mahasiswa pincang pun menjadi bulan-bulanan para tentara. Ia dipukul dan ditendang hingga terjatuh di atas tanah. Namun, sangat disayangkan, setelah bentrokan berakhir pemerintah Mesir tidak mengambil langkah penyelesaian apapun.

$$
\begin{aligned}
& \text { لم تحقق في إصابة عشرات الطلاب الذين حملهم } \\
& \text { زملائهم إلى الحرم الجامعي، وكان بعضهم مصابا في رأسه }
\end{aligned}
$$

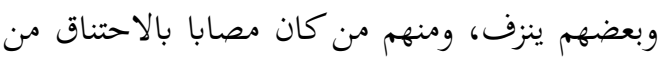

$$
\begin{aligned}
& \text { القنابل المسيلة للدموع، أو فاقدا للوعي (عاشور، }
\end{aligned}
$$

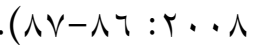

"Kejaksaan tidak menyelidiki puluhan mahasiswa terluka yang dibawa oleh teman-teman mereka ke dalam kampus. Sebagian dari mereka terluka di kepala dan sebagian mengalami pendarahan. Di antara mereka ada yang tersedak gas air mata dan pingsan" (Ashour, 2008b: 86-87).

Kutipan ini menegaskan bahwa pihak berwenang Mesir tidak mengambil langkah tegas. Begitu juga dengan Kejaksaan Mesir yang tidak melakukan penyelidikan terhadap pelanggaran HAM yang terjadi dalam persitiwa bentrokan itu. Pada akhirnya mereka menutup kasus tersebut tanpa kejelasan apapun. 


\section{Kesimpulan}

Sesuai dengan pandangan dunia Radwa Ashour sebagai penulis novel Faraj yang diketahui dengan memanfaatkan teori Strukturalisme Genetik, perlawanan mahasiswa Mesir terjadi karena tiga faktor, yaitu perubahan pola pikir masyarakat, pemberontakan mahasiswa Perancis 1968, dan penerapan kebijakan Infitāch. Perlawanan dilakukan dengan bentuk kegiatan simposium, penulisan artikel, dan unjuk rasa. Namun, perlawanan ini dapat dibungkam oleh pemerintah yang berkuasa dengan kekuatan militer melalui penggeledahan dan penangkapan, pemenjaraan, perusakan majalah dinding, serta kekerasan dan penganiayaan.

Dari pandangan dunia penulis juga dapat diketahui bahwa pembungkaman terhadap pergerakan mahasiswa anti kapitalisme terjadi akibat perbedaan pandangan politik dan kepentingan. Para mahasiswa menginginkan kemerdekaan dan kesejahteraan untuk seluruh bangsa Mesir, sedangkan pemerintah mereka menjalin kerja sama dengan negara kapitalis yang menyebabkan kerugian bagi bangsa Mesir.

\section{Daftar Pustaka}

Anon. n.d. "Events of May 1968 Background, Significance, \& Facts Britannica." Retrieved April 17, 2021 (https://www.britannica.com/event/e vents-of-May-1968).

Arafat, Alaa al-Din. 2009. The Mubarak Leadership and Future of Democracy in Egypt. New York: St. Martin's Press.

Ashour, Radwa. 2008a. Arab Woman Writers: A Critical Reference Guide 1873-1999. Cairo: American University in Cairo Press.

Ashour, Radwa. 2008b. Faraj. Cairo: Dar el-Shuruq.

Erlich, Haggai. 1989. Students and University in Twentieth Century Egyptian Politic. London: Frank Class.

Faksh, Mahmud. 2005. "The
Concequences of the Introduction and Spread of Modern Education." in Modern Egypt Studies in Politics and Society. London: Frank Class.

Faskh, Mahmud A. 2005. "The Consequences of the Introduction and Spread of Modern Education." in Modern Egypt Studies in Politics and Society. London: Frank Class.

Goldmann, Lucien. 1967. "The Sociology of Literature: Status and Problem of Method." in Sociology of Literary Creativity. Paris: International Sosial Science Journal.

Goldmann, Lucien. 1973. "Genetic Structuralism in the Sociology of Literature." in Sociology of Literature and Drama. London: Penguins Books Ltd.

Goldmann, Lucien. 1980. Essays on Method in The Sociology of Literature. New York: Telos Press.

Goldmann, Lucien. 2013. The Hidden God: A Study of Tragic Vision in the Pensées of Pascal and the Tragedies of Racine. London: Routledge and Keagan Paul.

Goldschmidt, Arthur. 2008. A Brief History of Egypt. New York: Infobase Publishing.

Hartman, Michelle. 2015. "The Journey by Radwa Ashour." Comparative American Studies 13(4):209-19. doi: 10.1080/14775700.2015.1178943.

Hobbs, Joseph. 2007. Egypt. New York: Chelsea House Publisher.

King, Stephen. 2009. The New Authoritarianism in The Middle East and North Africa. Bloomington: Indiana University Press.

Michelmore, Christina W. 1983. "Student Politics in Egypt 1922-1952." University of Pennsylvania.

Sihbudi, Riza, and Et.all. 1995. Profil Negara-Negara Timur Tengah Buku 1. Jakarta: PT. Dunia Pustaka Jaya.

Syam, Firdaus. 2007. Pemikiran Politik 
Barat Sejarah, Filsafat, Ideologi, Dan Pengaruhnya Terhadap Dunia Ketiga. Jakarta: PT. Bumi Aksara.

Thayib, Anshary, and Anas Sadaruwan. 1981. Anwar Sadat Di Tengah Teror Dan Damai. Surabaya: PT. Bina Ilmu.

Vatikiotis, P. J. 1978. Nasser and His Generation. London: Croom Helm. 